\title{
POLICING IN AMERICAN HISTORY
}

\author{
Robert A. Brown \\ Department of Criminal Justice, North Carolina Central University
}

\begin{abstract}
This article examines the historical evolution of policing in America with a focus on race. Specifically, it is argued that racial bias has deep roots in American policing, and reforms in policing and American society have not eliminated the detrimental experiences of Blacks who encounter the police. Historical information and contemporary empirical research indicate that, even when legal and other factors are equal, Blacks continue to experience the coercive and lethal aspects of policing relative to their non-Black counterparts.
\end{abstract}

Keywords: Racial Bias, Arrest, Use of Force, Community Policing

\section{INTRODUCTION}

The historical stains of racism and related ills are part of the history and traditions of American policing. In the American context, race and class have always been central to the role that law enforcement agencies and the law enforcement officer play in our society. This paper will discuss how, despite some progress in making policing more just for racial and ethnic minorities, racial injustices still permeate our systems of policing and criminal justice. The incidents of racial bias and injustice that we see today, particularly in regard to arrest and the use of force, are not isolated or disconnected from the origins and evolution of American law enforcement. The empirical literature on discretion and police actions involving use of force and arrest prove that race matters in how people experience policing, and that experience of racial discrimination is part of a long history of injustices perpetrated by those who are supposed to stop injustices—the police.

\section{HISTORY OF RACE AND POLICING}

\section{Origins}

"[T]he history of American police strategies cannot be separated from the history of the Nation as a whole. Unfortunately, our police, and all of our other institutions, must contend with many bitter legacies from that larger history. No paradigm — and no society—can be judged satisfactorily until those legacies have been confronted directly" (William and Murphy, 1990, p.13). 
The history of policing in America is often told through discussions of eighteenth and nineteenth-century urban centers, primarily in the Northern regions of our nation. Big city American policing in the Northern parts of the nation was influenced by the model of policing established in London, England through the Metropolitan Police Act of 1829 and the philosophies of Sir Robert Peel (Walker 1983). While this may be true of the North, American policing developed differently in the Frontier and Southern regions of the nation. Each of these regions differed in how they were socially organized, which power groups controlled or strongly influenced societal functions, and in their real and perceived social problems. Robert H. Langworthy and Lawrence F. Travis (1999) note that policing can be (must be) understood through a "balance of forces," (p. 37) and this starts with recognizing that law enforcement in the United States as a whole did not evolve from a simplistic replication of British policing. Due to the similarities between London, England and urban cities in the North (e.g., Boston, Chicago, New York, Philadelphia, etc.) regarding industrialization, political and industrial elites, and the challenges associated with rapid immigration/migration, policing in the North used London as its template for policing. Law enforcement evolved differently in the South and Frontier, and the conditions and traditions of these regions are important parts of the fabric of American policing (Turner et al., 2006).

Building a model of policing from a big city blueprint, copying the Northeastern or British model, was not tenable for early forms of policing in the South and the Frontier as large urban centers were not the norm. The South required a form of policing that empowered both elites and poor Whites with the ability to deal with the institution of slavery. In many towns and settlements, enslaved and freed Blacks outnumbered Whites. Threats to the institution of slavery (i.e., revolts, escapes) and maintaining the supremacy of Whites over Blacks were significant regional concerns (Bass 2001). In response to these concerns, the protection of Whites, and the formal policing of Blacks, was solidified through the establishment of slave patrols (Reichel 1988). As Dulaney (1996) notes, "the slave patrol was the first distinctly American police system, and it set the pattern of policing that Americans of African descent would experience throughout their history in America" (p. 2). Enslaved and freed Blacks lived in fear as slave patrols operated with impunity in subjecting Blacks to stops, searches, physical beatings, detentions, re-enslavement, and lynching (Dulaney 1996; Jones-Brown 2007; Reichel 1988; Williams and Murphy, 1990).

In the Frontier, policing developed in places where people were attempting to settle the lands of indigenous peoples and regulate spaces that they did not own or fully control. Legal authority in regard to government, land rights, and social issues was not always clear, and the absence of well-structured or formal law enforcement entities gave way to extralegal enforcement of laws and norms (Langworthy and Travis, 1996). Posse and vigilante justice were typical responses to situations involving ineffective law and order, which was not limited to the American Frontier; indeed, the first documented vigilante movement occurred in 1767 in Piedmont, South Carolina (Brown 1983). While vigilantism was not limited to the settlement of the West, those responsible for enforcing the law in this region were not above violating the law (or not stopping others from violating the law) when dealing with problems.

It is important to understand how policing developed in the early stages, in the early history and traditions of these regions, because over time policing in America became a blend of these traditions and practices. Changes in technology, laws, the development and implementation of professional standards, and changes in societal norms have surely improved many aspects of American policing. However, with all of the changes and advances related to policing, Blacks in America continue to experience differential enforcement behavior as some police officers still behave in ways that reinforce economic and racial segregation, and injustice (Bass 2001; Boyles 2015). 


\section{Community Policing and the Continuation of Racial Injustice}

Community policing has been a movement to transform local law enforcement beyond the problems that society and the police experienced in previous historical eras, such as inefficacies in dealing with crime, police misconduct and corruption, and poor police-minority community relations (Oliver 2006). The professional model of policing and the emphasis on crime control through focusing on law enforcement activities (more so than order maintenance and service activities) were partially blamed for significant incidents of social unrest and unexpected increases in crime rates. A change in philosophy and strategy was the next reform effort (Kelling and Moore, 1989).

This change in philosophy and strategies was facilitated through a significant rewrite of the history of American policing (Walker 1984). In 1982, James Q. Wilson and George L. Kelling made a call for a return to order maintenance policing, a return to the "good old days" of watchman-style policing. They noted that in the earliest days of formal policing there was a heavy emphasis on maintaining order, but over time law enforcement became the primary focus of police activities. Wilson and Kelling (1982) successfully advanced the concept that unchecked incidents of disorder (i.e., the "Broken Window" that does not get fixed in some communities) leads to more disorder, and eventually crime. Law enforcement professionals embraced the broken-windows metaphor and readily folded it into the doctrine of community policing. Moving in this direction emphasized discretion at the street level (Skogan 2018) and encouraged officers to use their authority to address individuals and situations that were "out of place" or "out of order" so that nothing more problematic or criminal would happen (Brown 2005). Under the guise of community policing being practiced to both reduce crime and improve relationships with communities, proactive policing strategies and tactics have been legitimized in the eyes of many (National Academies of Sciences, Engineering, and Medicine, 2018a; Skogan 2018). As Delores Jones-Brown notes, "[ $t$ ]he collateral consequences of contemporary policing practices reinforce criminalization as both a spatial and racial phenomenon: the label of criminality easily transferred from neighborhoods to their residents" (National Academies of Sciences, Engineering, and Medicine, 2018b, p. 2). When it comes to street-level policing, regardless of being in- or out-of-place, Blacks still disproportionately experience surveillance, stops, searches, detentions, arrests, and force that cannot be easily explained away by legal factors (Jones-Brown 2000, 2007; Meehan and Ponder, 2002).

\section{RESEARCH AND FINDINGS}

The need for rigorous empirical research on police behavior became more apparent after formal reviews of law enforcement were conducted in the 1960s. Findings from the U.S. President's Commission on Law Enforcement and the Administration of Justice, The Challenge of Crime in a Free Society (1967) and the Kerner Commission (1968) were clear that relations between the police and minority communities were very poor and that at the hands of the police, Blacks experienced differential and heavy-handed justice (Skogan 2018). Concerns over how race is related to policecitizen interactions, in particular the outcome of encounters between Blacks and the police, was one of the engines behind more scientific research on policing (National Research Council, 2004). Arrest and the use of force in the form of fatal shootings have been two of the most researched, and most controversial, aspects of policing. 


\section{Arrest}

Through systematic social observations of the police, researchers have been able to collect data on the characteristics of police-citizen encounters and perform multivariate analyses that attempt to account for legal factors (e.g., offense conduct) and extralegal factors (e.g., race/ethnicity, gender, demeanor, etc.) (National Research Council, 2014). With a good bit of consistency, scholars have found that arrest is more likely to happen when officers encounter suspects who commit more serious offenses (i.e., felonies versus misdemeanors), when suspects are disrespectful [in the eyes of the police], and when victims request that the police take action against a suspect. For many years policing scholars reported mixed or inconclusive findings regarding how the race of a suspect influenced arrest outcomes, which prompted some to claim that empirically there was not enough evidence to support claims that Blacks were more likely to be arrested because of their race (National Research Council, 2014). However, strong evidence does exist on the effects of a suspect's race on an officer's decision to arrest, and it is consistent with the bias against Blacks that has been documented throughout the history of their interactions with law enforcement.

Seeking to provide clarity on the effects of suspect race and other factors found to be important in studies on arrest outcomes, Kochel et al. (2011) conducted a rigorous meta-analysis of approximately forty studies using twenty-three different datasets spanning data collected between 1966 and 2004. Results from their meta-analysis revealed that a suspect's race is a statistically significant factor in arrest outcomes, even when controlling for a suspect's offense conduct, display of respect for the police, victim presence or preference, and other relevant legal and extralegal factors. More specifically, it was found that the chances of arrest for minority suspects are thirty percent higher than that of White suspects (Kochel et al., 2011). Based on these findings, there should be no question about whether race matters when it comes to the literature on officer arrest decision making. Questions to be resolved by scholars, policy makers and criminal justice professionals is developing an understanding of why it still matters (and matters so much), and what will be done to address it.

\section{Use of Force}

The use of deadly force by law enforcement officers is rare (Nix et al., 2017). Research suggests that less than two percent of police contacts involve any use of force, physical or verbal, and the use of force to control a resistant suspect during an arrest happens between fifteen to twenty percent of the time (Smith et al., 2009). Rare events that may be homicides are important events, particularly when law enforcement officers are involved. Moreover, police use of force against Blacks and other minorities has been the most controversial and volatile issue in policing (Paoline et al., 2016). Unfortunately, within this realm of rare events, both history and available data show an enduring pattern of Blacks losing their lives to police violence disproportionately to their White counterparts (Fernandes and Crutchfield, 2018).

Understanding police use of force through research is challenging because, compared to the data and scholarly literature on police behaviors like arrest, we do not have good access to data that would allow for rigorous analysis of factors present during encounters where the police use force. The Center for Policing Equity analyzed five years of data (2010-2015) from twelve different police departments voluntarily participating in the National Justice Database (Goff et al., 2016). Goff and his colleagues found that, "[R]acial disparities in police use of force persist even when controlling for racial distribution of local arrest rates," (p. 4) and this was the case for officer use of Tasers, OC spray, and use of hand/body techniques. 
Where federal and local government has failed in establishing mandatory or comprehensive reporting systems on police encounters where force is used, rigorous analyses of the use of force incidents has evolved in recent years (Garner et al., 2018), particularly around fatalities. Analysis of the well-recognized National Police Shooting Database, created by The Washington Post, found that unarmed Blacks were twice as likely to be fatally shot by the police as unarmed Whites (Nix et al., 2017). Ross (2015) analyzed police shootings 2011-2014 at the county level and found that the probability of being Black, unarmed, and fatally shot by the police for Blacks was 3.49 times higher than it was for unarmed Whites. Ross (2015) notes that "Tragically, across a large proportion of counties, individuals who were shot by police had a higher median probability of being unarmed black individuals than being armed white individuals (p. 12, original emphasis). These finding were more likely to be found in larger metropolitan counties, in counties with larger Black populations, and in counties with higher levels of financial inequality. Furthermore, the influence of crime rates was examined and the greater likelihood of being Black and fatally shot while unarmed was unrelated to levels of crime. Building on fatal police shootings data from the Mapping Police Violence project, public health scholars have studied the issue as a function of state-level structural racism. Aldina Mesic and colleagues (2018) created an index measure of structural racism that included a state's level of residential segregation and gaps between Blacks and Whites in incarceration rates, educational attainment, employment status, and economic disparity (i.e., the gap in proportion living under the poverty level, median household income, and proportion of home owners to renters). Their results found that during 2013-2015, states with a higher racism index had significantly higher racial disparities in rates of police shootings of unarmed individuals. Unarmed Blacks were shot at a rate 4.5 times higher than unarmed Whites, and the overall racism index ranged 25.9 in Montana to 74.9 in Wisconsin (Mesic et al., 2018). With the history of policing in America and other empirical findings on her side, Mesic and her colleagues conclude that, "gaps in employment, education, and incarceration and racial residential segregation are markers for a history of structural violence that in turn may be associated with differences in the way police interact with Black versus White suspects" (2018, p. 114).

\section{CONCLUSION}

Overt, visible acts of racial discrimination by the police are less likely to be acceptable today. Race remains a significant factor in policing. Acknowledging these two statements is necessary when it comes to understanding racial inequity in policing. Indeed, the effects of race on law enforcement are complex and arguably operate in conjunction with other factors which facilitate bias and disparity in American law enforcement. Discussing racial inequality and injustice in law enforcement must involve a discussion of how race started to be a factor in American policing. There must be recognition that race was a significant factor in how policing evolved into what we see today. It must be recognized that anecdotal and qualitative information reported over time about how Blacks experience policing is more consistent with the empirical (quantitative) literature than some believe (Brunson 2007). The evidence on how race is related to bringing Blacks into the Criminal Justice System (i.e., arrests), and on how much race is a factor in the deaths of unarmed Blacks (i.e., fatal police shootings) makes it impossible to credibly say that racial bias in policing is a "thing of the past" and that policing is just for all.

Corresponding author: Robert A. Brown, Department of Criminal Justice, North Carolina Central University, 302 Whiting Criminal Justice Building, 1801 Fayetteville Street, Durham, North Carolina, 27707. E-mail: rabrown@ @ccu.edu 


\section{REFERENCES}

Bass, Sandra (2001). Policing Space, Policing Race: Social Control Imperatives and Police Discretionary Decisions. Social fustice, 28 no.1 (83): 156-176.

Boyles, Andrea S. (2015). Race, Place, and Suburban Policing: Too Close for Comfort. Oakland, CA: University of California Press.

Brown, Robert A. (2005). Black, White, and Unequal: Examining Situational Determinants of Arrest Decisions from Police-Suspect Encounters. Criminal fustice Studies, 18(1): 51-68.

Brown, Robert M. (1983). Vigilante Policing. In Carl B. Klockars and Stephen D. Mastrofski (Eds.) Thinking About Police: Contemporary Readings. New York: McGraw-Hill.

Brunson, Rod K. (2007). “Police Don't Like Black People:” African-American Young Men's Accumulated Police Experiences. Criminology \& Public Policy, 6(1): 71-101.

Dulaney, W. Marvin (1996). Black Police in America. Bloomington, IN: Indiana University Press.

Fernandes, April D., and Robert D. Crutchfield (2018). Race, Crime, and Criminal Justice: Fifty Years Since The Challenge of Crime in a Free Society. Criminology \& Public Policy, 17(2): 397-417.

Garner, Joel H., Matthew J. Hickman, Ronald W. Malega, and Christopher D. Maxwell (2018). Progress Toward National Estimates of Police Use of Force. PloS one, 13(2). <https://doi. org/10.1371/journal.pone.0192932> (Accessed April 3, 2019).

Goff, Philip Atiba, Tracy Lloyd, Amanda Geller, Steven Raphael, and Jack Glaser. (2016). The Science of Justice: Race, Arrests, and Police Use of Force. New York: Center for Policing Equity. <http://policingequity.org/wp-content/uploads/2016/07/CPE_SoJ_Race-ArrestsUoF_2016-07-08-1130.pdf $>$ (Accessed April 3, 2019).

Jones-Brown, Delores D. (2000). Debunking the Myth of Officer Friendly: How African American Males Experience Community Policing. Fournal of Contemporary Criminal fustice, 16(2): 209-229.

Jones-Brown, Delores (2007). Forever the Symbolic Assailant: The More Things Change, the More They Remain the Same. Criminology \& Public Policy, 6(1): 103-121.

Kelling, George L., and Mark H. Moore (1989). The Evolving Strategy of Policing. Washington, DC: U.S. Department of Justice, Office of Justice Programs, National Institute of Justice. <https://pdfs.semanticscholar.org/a614/21a27a6c4fa0e25962 ef30e95a22371c1b9c.pdf> (Accessed April 4, 2019).

Kochel, Tammy Rinehart, David B. Wilson, and Stephen D. Mastrofski (2011). Effect of Suspect Race on Officers' Arrest Decisions. Criminology, 49(2): 473-512.

Langworthy, Robert H., and Lawrence F. Travis III, (1999). Policing in America: A Balance in Forces. Upper Saddle River, NJ: Prentice Hall Publishing.

Meehan, Albert J., and Michael C. Ponder (2002). Race and Place: The Ecology of Racial Profiling African American Motorists. Fustice Quarterly, 19(3), 399-430.

Mesic, Aldina, Lydia Franklin, Alev Cansever, Fiona Potter, Anika Sharma, Anita Knopov, and Michael Siegel (2018). The Relationship Between Structural Racism and Black-White Disparities in Fatal Police Shootings at the State Level. Fournal of the National Medical Association, 110(2): 106-116.

National Academies of Sciences, Engineering, and Medicine (2018a). Proactive Policing: Effects on Crime and Communities. Washington, DC: The National Academies Press. <https://doi. org/10.17226/24928> (Accessed April 4, 2019).

National Academies of Sciences, Engineering, and Medicine (2018b). The Criminal fustice System and Social Exclusion: Race, Ethnicity, and Gender: Proceedings of a Workshop—in Brief. Washington, DC: The National Academies Press. <https://doi.org/10.17226/25247> (Accessed April 4, 2019).

National Research Council (2004). Fairness and Effectiveness in Policing: The evidence. Washington, DC: The National Academies Press.

Nix, Justin, Bradley A. Campbell, Edward H. Byers, and Geoffrey P. Alpert (2017). A Bird's Eye View of Civilians Killed By Police in 2015: Further Evidence of Implicit Bias. Criminology \& Public Policy, 16(1): 309-340.

Oliver, Willard M. (2006). The Fourth Era of Policing: Homeland Security. International Review of Law Computers \& Technology, 20(1-2): 49 -62.

Paoline, Eugene A., Jacinta M. Gau, and William Terrill (2016). Race and the Police Use of Force Encounter in the United States. The British Fournal of Criminology, 58(1): 54-74.

Reichel, P. L. (1988). Southern Slave Patrols as a Transitional Police Type. American fournal of Police, 7(2): 51-77.

Skogan, Wesley G. (2018). The Commission and the Police. Criminology \& Public Policy, 17(2): 379-396. 
Turner, K. B., David Giacopassi, and Margaret Vandiver (2006). Ignoring the Past: Coverage of Slavery and Slave Patrols in Criminal Justice Texts. Fournal of Criminal Fustice Education, 17(1): 181-195.

U.S. President's Commission on Law Enforcement and Administration of Justice (1967). The Challenge of Crime in a Free Society. Washington, DC: U.S. Government Printing Office.

United States National Advisory Commission on Civil Disorders, and Otto Kerner (1968). Report of the National Advisory Commission on Civil Disorders, March 1, 1968. Washington, DC: U.S. Government Printing Office.

Walker, Samuel (1983). The Police in America: An Introduction. New York: McGraw-Hill.

Walker, Samuel (1984). "Broken Windows" and Fractured History: The Use and Misuse of History in Recent Police Patrol Analysis. Fustice Quarterly, 1(1): 75-90.

Williams, Hubert and Patrick V. Murphy (1990). The Evolving Strategy of Police: A Minority View (Vol. 13). Washington, DC: U.S. Department of Justice, Office of Justice Programs, National Institute of Justice.

Wilson, James Q., and George L. Kelling (1982). Broken Windows. Atlantic Monthly, 249(3): 29-38. 